Article

\title{
Emotional Self-Regulation through Introjective Practices in Physical Education
}

\author{
Dolors Cañabate ${ }^{1}$, Mónica Santos ${ }^{1}$, David Rodríguez ${ }^{2}$, Teresa Serra $^{3}{ }^{3}$ and Jordi Colomer ${ }^{3}, * \mathbb{C}$ \\ 1 Department of Specific Didactics, Faculty of Education and Psychology, University of Girona, \\ 17004 Girona, Spain; dolors.canyabate@udg.edu (D.C.); monica.santos@udg.edu (M.S.) \\ 2 Department of Arts, Swiss Cancer League, 1003 Lausanne, Switzerland; david.rodriguez@lvc.ch \\ 3 Department of Physics, Polytechnic School Faculty, University of Girona, 17003 Girona, Spain; \\ teresa.serra@udg.edu \\ * Correspondence: jordi.colomer@udg.edu
}

Received: 24 June 2020; Accepted: 11 August 2020; Published: 13 August 2020

\begin{abstract}
This study analyzed emotional self-regulation in relation to K-9 and K-10 school children's emotional intelligence defined on three dimensions: Emotional attention, clarity of feelings, and emotional repair. The objective was to analyze the students' perceptions of skills and capacities that promoted the awareness of emotions when performing introjective motor practices, i.e., motor skill exercises in which the inner logic provokes a process of sensorial self-awareness and psychosomatic balance. A total of 90 fourth-year primary school students from four different schools participated in the study and a reduced version of the Trait-Meta Mood Scale (TMMS) questionnaire was used to measure students' individual self-regulation. First, pre- and post-test results showed significant differences with a $20.1 \%$ improvement in the three dimensions of intrapersonal emotional attention (emotional attention, clarity of feeling, and emotional repair) after having performed a set of in-class introjective practices. Second, while there were no significant differences between the boys and girls during the pre-test, significant changes-an $8.1 \%$ difference-were found in the post-test results for girls.
\end{abstract}

Keywords: physical education; self-regulation; introjective practices; emotional intelligence

\section{Introduction}

One of the main educational purposes of schools is to guarantee the overall development of individuals, preparing them to be able to cope with social demands. In recent years there has been a sharp growth in practices focusing on improving young people's health [1] and developing emotional competences, as well as self-awareness and emotional regulation [2-5]. Different authors have established specific areas and contents to ensure that the purpose of primary education (PE) is to provide children with the competences that will enable their personal and social development [6]. The education system must provide emotional education which helps the individual develop good socialization skills and the emotional competences that will enable them to enjoy personal well-being [7].

Emotions are an undeniable and integral part of a human being which condition physical and mental health while also playing a key role in behavior, learning, and interaction with others [8-10]. Furthermore, a link is established between what we feel and our control over our thoughts and behavior in such a way that we experience different emotions on a constant basis which, in turn, influence our actions [11,12]. In view of this, numerous authors highlight the importance of becoming aware of our own emotions and putting a name to what we feel $[13,14]$. For this reason, it is vital to provide individuals with emotional education. 
At present, different studies focus on the concept of emotional intelligence in order to promote awareness of one's emotions and to develop personal well-being $[1,12,13,15]$. This task involves: (1) Being aware of our own emotions and what happens to us, and knowing how to name emotions to distinguish between them; (2) controlling and managing what we feel, which can be achieved once the first step has been attained; and (3) recognizing other people's emotions in order to establish links with the community. On this point, the educational aim of PE is to help students acquire knowledge, skills, and competences related to the body that contribute towards the overall development of the person and to the improvement of their quality of life.

As authors such as Lagardera [16], Bisquerra [7], and Grewall et al. [17] note, PE offers an appropriate educational setting for the acquisition of emotional competences. The different motor practices carried out in PE offer a variety of different emotional responses [18-21], since each task or sporting activity has a different internal logic that stimulates different processes and responses [12]. The objective is to promote motor skills that prompt participants to resolve problems associated with relations with others, with space, time, or material $[3,4]$. These relations mean that participants undergo different processes in each motor practice. Introjective motor practices are underpinned by an internal logic that stimulates, among others, self-awareness, body control, and overall well-being [16] through exercises involving conscious breathing, joint freeing, stretching, or full attention carried out individually. Introjective motor practices (IMP) such as meditation, yoga, Tai Chi, and mindfulness present an internal logic that aims to stimulate self-knowledge, self-awareness, emotional self-control, physical and/or mental well-being, reduce stress and negative emotions, encourage positive states of mind to flourish, as well as calmness, relaxation, and body control through conscious breathing exercises, joint freeing, and stretching $[1,16,22]$.

Mindfulness is the English translation of the word 'Sati' (in the Pali language), which means awareness, attention, and recall. Being conscious means being aware of what is occurring within ourselves (thoughts, emotions, bodily sensations, etc.) and/or outside (smells, sounds, people, objects, etc.). Attention occurs when awareness is focused on one stimulus, for example, on breathing or on the body. In terms of recall, this refers to the act of remembering to be conscious and to pay attention. Mindfulness, or full attention, is an IMP that focuses on paying conscious attention to the experience of the present moment [4]. The aim is therefore to learn or reinforce competences which are closely linked to emotional intelligence, such as self-awareness. For instance, being at one with one's inner self in order to be able to observe what and how one feels. This provides an excellent means of developing emotional self-knowledge [23] since it aims to promote emotional management in a progressive manner [12], thereby building and developing the overall well-being of the individual [7].

Various studies [1,24-26] have shown the physical and psychological benefits of self-knowledge and personal management in individuals who carry out systematized practices such as meditation, yoga, Tai Chi, or mindfulness. Moreover, other studies [27-29] involving PE with secondary school students, have obtained significant results in relation to emotional control and reducing behavioral problems thanks to school mindfulness programs that use tasks such as meditation or conscious breathing.

Along the same lines of research, numerous tertiary universities are conducting studies on the effects of a mindfulness program in primary and secondary education in order to help young people to regulate their emotions [30] and enjoy physical and mental well-being [1,31,32]. Some authors posit that introjective practices might be an innovative educational approach for students to experience emotions that can help in the acquisition of skills [7,18]. In this study, self-regulation is understood to be the capacity to recognize individual emotions and to act accordingly, mitigating states of tension, stress, anxiety, or pain, in pursuit of well-being and psychosomatic balance [33]. The importance of these competences means that it is vital that schools promote them.

The objective of this study is to test the validity of a mindfulness educational approach and to verify if introjective practices promote emotional self-regulation in primary school students. In particular, attention is focused on developing the socio-emotional or socio-personal competences that help to promote self-knowledge and the self-regulation of emotions. 


\section{Materials and Methods}

\subsection{Participants}

The sample was comprised of 90 fourth-year PE students, with a mean age of 9.5 years, with $40 \%$ $(n=36)$ being boys and $60 \%(n=54)$ girls. Students were split into four classes from four schools and, since the characteristics of the schools matched our research interests, all groups were considered as one single convenience sample. In addition to the researchers, eight primary school teachers also participated in the study; four PE specialists and four fourth-year general education teachers $(n=8$; aged between 26 and 36 years old; $M=32$ ).

\subsection{Ethical Considerations}

The entire research process was carried out with the prior authorization of the teachers and students involved. All the participants were informed of the objectives of the study, as well as the conditions for participation. The use of data took into account ethical principles and ensured anonymity. This study was approved by the Research Ethics Committee (REC) of the University of Girona in 2019.

\subsection{Procedure}

The study was structured into three phases (Table 1). In line with Cañabate et al. [34], the aim was to create a specific classroom climate to motivate students to participate in the practices developed during all phases of the research project. In this way, intrinsic motivation and task organization were closely linked to a motivational climate focused on the task at hand [20]. It is important to remember that classroom climate is an essential element that predisposes and determines social relations within the teaching and learning process (Sánchez et al., 2016). In the first phase, the whole program was explained to the students, including the set of six introjective motor practices, and the Trait-Meta Mood Scale (TMMS) questionnaire $[35,36]$ was presented.

In this first phase (Week One) the TMMS questionnaire was distributed (pre-test treatment). In the second phase, classes were devoted to putting into practice the six introjective practices: Yoga, Tai Chi, eutony, active global stretching, Qi-gong, and corporal dance expression (Table 1). The intervention phase of this project was carried out in PE sessions four days a week, therefore, the intervention lasted for a full six weeks. Each of the introjective practices was linked to the physical education objectives as defined in the Spanish curriculum for the middle cycle of PE (Table 1) and to a set of specific competences (Table 2), and also to the assessment of physical activity in relation to health and well-being, and/or the development of expression of emotions and feelings through the body, gesture, and movement, which are at the very core of promoting the development of personal well-being and emotional intelligence. In the third phase (Week Eight) the TMMS questionnaire was distributed (the post-test treatment) and the results were discussed between the primary school students and their teachers.

During the six intervention sessions, students followed a ritual upon entering or exiting class. The ritual on entering consisted of four minutes of silence, in which students relaxed, and which also helped to create a suitable climate for starting the class. Likewise, a ritual for leaving that consisted of reflecting on how the class had gone, what new experiences or emotions they had experienced, and/or any anecdotes they wanted to share with their peers was also included. 
Table 1. Definition of the six introjective practices, and the associated physical education objectives.

\begin{tabular}{|c|c|}
\hline Introjective Practices & Physical Education Objectives \\
\hline $\begin{array}{l}\text { Yoga (PE1): A technique that improves psychological and cognitive } \\
\text { parameters as well as sports performance. Reduces symptoms of } \\
\text { perceived stress, worry, depression, and increases the state of } \\
\text { mindfulness. Greater awareness of the musculature is also } \\
\text { observed after performing conscious breathing techniques and } \\
\text { paying attention to the parts of the body. }\end{array}$ & $\begin{array}{l}\text { Develop conscious breathing, specifically, } \\
\text { abdominal diaphragmatic, rib cage, and } \\
\text { lumbar respiration. }\end{array}$ \\
\hline $\begin{array}{l}\text { Tai chi (PE2): A technique used to improve the physical, mental, } \\
\text { and spiritual quality of life. Tai Chi is a type of movement } \\
\text { meditation, where the person who practices it is focused on the } \\
\text { here and now. }\end{array}$ & $\begin{array}{l}\text { Work on own movements that form } \\
\text { representations of nature. }\end{array}$ \\
\hline $\begin{array}{l}\text { Eutony (PE3): A discipline based on the experience of the body } \\
\text { itself, which leads the person to become aware of themselves. }\end{array}$ & $\begin{array}{l}\text { Develop awareness in order to be conscious } \\
\text { of the increase and decrease in muscle tone. }\end{array}$ \\
\hline $\begin{array}{l}\text { Active Global Stretching (PE4): A variant of global postural } \\
\text { re-education. It is an effective stretching technique for preventing } \\
\text { or improving injuries, as well as improving muscle performance. }\end{array}$ & $\begin{array}{l}\text { Develop balance exercises and muscle } \\
\text { synergy. Perform progressive stretches to } \\
\text { affect muscle tone in particular. }\end{array}$ \\
\hline $\begin{array}{l}\text { Qi-gong (PE5): This is a discipline that improves the regulation of } \\
\text { anxiety, depressive symptoms and self-efficacy. Its goals are to } \\
\text { improve health, relieve pain, eliminate stress, anxiety and } \\
\text { depression, and help to have more energy and vitality. }\end{array}$ & $\begin{array}{l}\text { Use breathing techniques through moderate } \\
\text { physical exercise. Combine breathing and } \\
\text { body postures. }\end{array}$ \\
\hline $\begin{array}{c}\text { Corporal Dance Expression (PE6): This is a discipline that improves } \\
\text { the motor behaviour of the individual with an expressive, } \\
\text { communicative and aesthetic purpose. It is based on the } \\
\text { development of movement with attention to the feelings of } \\
\text { the individual. }\end{array}$ & $\begin{array}{l}\text { Recognize the body as an instrument of } \\
\text { expression and communication. Work on } \\
\text { communication through body language. } \\
\text { Reflect on expression and communication } \\
\text { activities with the intention of improving } \\
\text { communication. }\end{array}$ \\
\hline
\end{tabular}

Table 2. Physical education competences that are linked (blackground in grey) to the six introjective practices (PE1 to PE6).

\begin{tabular}{|c|c|c|c|c|c|c|}
\hline Physical Education Competences & PE1 & PE2 & PE3 & PE4 & PE5 & PE6 \\
\hline \multicolumn{7}{|l|}{$\begin{array}{l}\text { Adequacy of consciousness and control of the body in relation to } \\
\text { tension, relaxation, and breathing. }\end{array}$} \\
\hline \multicolumn{7}{|l|}{$\begin{array}{l}\text { Discovery of organic and functional elements related } \\
\text { to movement. }\end{array}$} \\
\hline \multicolumn{7}{|l|}{ Experimentation with the body and movement. } \\
\hline \multicolumn{7}{|l|}{ Adaptation of movement to spatio-temporal structures. } \\
\hline \multicolumn{7}{|l|}{ Valuation of one's own bodily reality. } \\
\hline \multicolumn{7}{|l|}{$\begin{array}{l}\text { Assessment of physical activity in relation to health } \\
\text { and well-being. }\end{array}$} \\
\hline \multicolumn{7}{|l|}{$\begin{array}{l}\text { Use of laterality in relation to one's own body, the bodies of others, } \\
\text { and other objects. }\end{array}$} \\
\hline \multicolumn{7}{|l|}{ Use of static balance and dynamic balance in different situations. } \\
\hline \multicolumn{7}{|l|}{$\begin{array}{l}\begin{array}{l}\text { Resolution of the structure of space and time in motor actions } \\
\text { and situations. }\end{array}\end{array}$} \\
\hline \multicolumn{7}{|l|}{ Perception of effort during physical activity. } \\
\hline $\begin{array}{l}\text { Expression of emotions and feelings through the body, gesture, } \\
\text { and movement. }\end{array}$ & & & & & & \\
\hline
\end{tabular}

\subsection{Instrument}

The TMMS-24 is a version of the Trait-Meta Mood Scale (TMMS) developed by Salovey et al. [35], which was reduced, validated, and adapted into Spanish by Fernández-Berrocal et al. [13]. The TMMS-24 has been used as it is a specific instrument for analyzing students' emotional experiences (Table 3). It contains three extremely important dimensions for intrapersonal emotional competence, each of 
which included eight items (24 items in total): Emotional attention (the perception of emotions), clarity regarding feelings (the inner understanding of feelings), and emotional repair (the regulation of emotions), which can be defined in the following way [35]:

Table 3. The Trait Meta-Mood Scale 24, with 24 questions, in five-point Likert scale.

\begin{tabular}{|c|c|c|c|c|c|c|}
\hline 1 & I pay a lot of attention to my feelings. & 1 & 2 & 3 & 4 & 5 \\
\hline 2 & I am usually very conscious of what I feel. & 1 & 2 & 3 & 4 & 5 \\
\hline 3 & I usually spend time thinking about my emotions. & 1 & 2 & 3 & 4 & 5 \\
\hline 4 & I think my emotions and state of mind deserve to be paid attention to. & 1 & 2 & 3 & 4 & 5 \\
\hline 5 & I allow my feelings to affect my thoughts. & 1 & 2 & 3 & 4 & 5 \\
\hline 6 & I constantly think about my state of mind. & 1 & 2 & 3 & 4 & 5 \\
\hline 7 & I often think about my feelings. & 1 & 2 & 3 & 4 & 5 \\
\hline 8 & I pay a lot of attention to the way I feel. & 1 & 2 & 3 & 4 & 5 \\
\hline 9 & My feelings are clear to me. & 1 & 2 & 3 & 4 & 5 \\
\hline 10 & I can usually define my feelings. & 1 & 2 & 3 & 4 & 5 \\
\hline 11 & I nearly always know how I feel. & 1 & 2 & 3 & 4 & 5 \\
\hline 12 & I usually know how I feel about people. & 1 & 2 & 3 & 4 & 5 \\
\hline 13 & I often become aware of my feelings in different situations. & 1 & 2 & 3 & 4 & 5 \\
\hline 14 & I can always say how I feel. & 1 & 2 & 3 & 4 & 5 \\
\hline 15 & I can sometimes say which emotions I am experiencing. & 1 & 2 & 3 & 4 & 5 \\
\hline 16 & I can manage to understand my feelings. & 1 & 2 & 3 & 4 & 5 \\
\hline 17 & I usually have an optimistic outlook, although I sometimes feel sad. & 1 & 2 & 3 & 4 & 5 \\
\hline 18 & Even when I feel sad, I try to think about pleasant things. & 1 & 2 & 3 & 4 & 5 \\
\hline 19 & When I am sad, I think about all life's pleasures. & 1 & 2 & 3 & 4 & 5 \\
\hline 20 & I try to have positive thoughts even when I feel bad. & 1 & 2 & 3 & 4 & 5 \\
\hline 21 & $\begin{array}{l}\text { If I think about things too much and end up complicating them, I try to } \\
\text { calm myself down. }\end{array}$ & 1 & 2 & 3 & 4 & 5 \\
\hline 22 & I am concerned about having a good state of mind. & 1 & 2 & 3 & 4 & 5 \\
\hline 23 & I have a lot of energy when I feel happy. & 1 & 2 & 3 & 4 & 5 \\
\hline 24 & When I am angry, I try to change my state of mind. & 1 & 2 & 3 & 4 & 5 \\
\hline
\end{tabular}

Emotional attention: The person is capable of feeling and expressing their emotions and feelings in an appropriate way. Emotional perception refers to the capacity to consciously recognize one's own emotions, to identify them and put the appropriate name to them.

Clarity of feelings: The person is fully aware of their own emotional feelings. Emotional understanding allows us to integrate what we feel into our thinking and to be able to consider the complexity of emotional changes.

Emotional repair: The person is able to regulate their emotional state correctly. Emotional regulation consists in managing both positive and negative emotions efficiently [13]. This aspect is closely related to resilience, a concept that currently attracts considerable attention insofar as it helps to reinforce the training of school children and sports people [37].

Participants were asked to score each of the items on a five-point Likert scale, from never (1), rarely (2), sometimes (3), fairly frequently (4), to very frequently (5), for each of the component scales. Answers to items 1 to 8 were added together to obtain the mean results for the emotional attention scale, likewise for answers to questions 9 to 16 providing information on emotional clarity, and answers to questions 17 to 24 in relation to emotional repair (Table 3).

SPSS $21^{\circledR}$ software was the statistics analysis tool used for the data. The database was entered onto a spreadsheet, and subsequently analyzed. Reliability of the questionnaire was obtained with the total of 90 samples. The reliability of each component of the TMMS questionnaire based on the calculated Cronbach's alpha for the three group categories for the post-test analysis (Phase 3) was $\alpha=0.83$. In addition, the test and retest reliability was appropriate since for the initial test (Phase 1), the Cronbach's alpha for the three group categories was calculated to be $\alpha=0.82$. The values to understand reliability are: $<0.60 ; 0.60 \geq$ uncertain $<0.70 ; 0.70 \geq$ acceptable $<0.80 ; 0.90 \geq \operatorname{good}<0.90$, 
and $\alpha \geq 0.90$ excellent, the experimental Cronbach's alpha for the pre- and post-test treatments ensured that the TMMS presented an excellent internal-consistency reliability.

Data for the pre-test and post-test treatments and for the overall (pre-test + post-test) were tested for homogeneity and normality. The post-test and pre + post-tests met these criteria, whereas the pre-test data had to be transformed as pre-test ${ }^{1 / 4}$. A two-way ANOVA with replicates was performed for the pre-test, post-test, and overall, with the aim of finding differences between treatments and gender.

\section{Results}

There were significant differences between the pre-test and the post-test $(<0.010)$ for the analysis of gender during the application of the treatments (Table 4). The mean range for the three dimensions of the TMMS for the pre-test were 2.96 for emotional attention, 3.03 for clarity of emotions, and 3.05 for emotional repair, with a total mean of $3.03 \pm 0.47$ (Table 4). The mean range for the three dimensions of the TMMS for the post-test were 3.53 for emotional attention, 3.67 for clarity of emotions, and 3.72 for emotional repair, with a total mean of $3.64 \pm 0.48$ (Table 3 ). Therefore, a difference of $20.13 \%$ was found for the overall pre-test and post-test mean results.

The highest differences between the pre- and post-test, in the dimension of the perception of emotions, i.e., emotional attention (Table 3), were obtained for question 8 (I pay a lot of attention to the way I feel), with a $26.0 \%$ difference, question 5 (I allow my feelings to affect my thoughts), with a $23.7 \%$ difference, and question 2 (I am usually very conscious of what I feel), with a $23.0 \%$ difference. In the dimension of clarity of feelings, referring to the inner understanding of feelings (Table 3), the highest differences between the tests were obtained for question 14 (I can always say how I feel), with a 35.8\% difference, question 16 (I can manage to understand my feelings), with a difference of $23.5 \%$, and question 15 (I can sometimes say which emotions I am experiencing) with a difference of $21.9 \%$. And finally, in the dimension of regulation of emotions, i.e., emotional repair (Table 4), the highest differences were observed for questions 18 (Even when I feel sad, I try to think about pleasant things), 21 (If I think about things too much and end up complicating them, I try to calm myself down), and 20 (I try to have positive thoughts even when I feel bad) with differences of $27.4 \%, 27.1 \%$, and $26.2 \%$, respectively.

The analysis also included information on differences with regard to gender for both pre-test and post-test treatments. In this case, significant differences were found between girls and boys for the post-test treatment $(p=0.007)$. For the post-test treatment, girls scored a mean of 3.76 and boys a mean of 3.48 (Table 5), with a total difference of $8.05 \%$. The results of the one-way ANOVA separated for girls and boys for the post-test treatment are presented in Table 5 . The interaction between the gender dimension and the treatments were not significant (Table 5).

Table 4. Statistical results of the two-way ANOVA with replicates for the different data sets considered, pre-test, post-test, and overall test. Mean values (M), standard deviation (SD), and $p$-values are included in the table, with ${ }^{* *}$ for the cases of $p<0.01$ (99\% confidence).

\begin{tabular}{ccc}
\hline Data Sets & Gender $\mathbf{M} \pm \mathbf{S D}$ & $p$-Value \\
\hline Pre-test treatment & $\begin{array}{l}\text { Girls 3.03 } \pm 0.52 \\
\text { Boys 3.02 } \pm 0.41\end{array}$ & 0.804 \\
\hline Post-test treatment & $\begin{array}{l}\text { Girls 3.76 } \\
\text { Boys 3.48 } \pm 0.50\end{array}$ & $0.007^{* *}$ \\
\hline Pre/post treatments & $\begin{array}{l}\text { Girls 3.39 } \pm 0.63 \\
\text { Boys 3.25 } \pm 0.47\end{array}$ & 0.530 \\
\cline { 2 - 3 } & $\begin{array}{l}\text { Pre-test 3.03 } \pm 0.47 \\
\text { Post-test 3.64 } \pm 0.48\end{array}$ & $<0.010^{* *}$ \\
\hline Gender $\times$ treatment test interaction & - & 0.058 \\
\hline
\end{tabular}


Table 5. One-way ANOVA for girls and boys for the post-test treatment. The degrees of freedom, the F and $p$-value, and the F critical for the ANOVA test have been included.

\begin{tabular}{ccccc}
\hline Gender & $d f$ & $\mathbf{F}$ & $p$-Value & $\mathbf{F}_{\text {crit }}$ \\
\hline Boys & 1 & 25.99 & $<0.01$ & 3.97 \\
Girls & 1 & 107.64 & $<0.01$ & 3.93 \\
\hline
\end{tabular}

\section{Discussion}

The main objective of this study was to gain knowledge on emotional education through implementing physical education introjective practices to help primary school students become more aware of their own emotions, to identify them and, consequently, to be able to manage them. Attention was focused, in particular, on the development of the socio-emotional or socio-personal competences that help promote self-knowledge and the self-regulation of emotions (Goleman, 1995). Results showed that the intake of emotional competences was balanced by the perception of emotions, the inner understanding of feelings, and the regulation of emotions. The educational approach based on the implementation of introjective practices largely impacted the primary school students on emotional attention, with students paying a lot of attention to the way they felt and also to the clarity of feelings, with students explicating that by carrying out the introjective practices, they can always say how they feel. In particular, this question was the one that produced the highest differences of $35.8 \%$ after applying the practices. Finally, in terms of emotional repair, students highly scored the questions relating to how the introjective practices make them think about pleasant things, have positive thoughts, and help them to calm down. Therefore, applying introjective practices to a physical education class might be an approach for stimulating self-awareness processes in primary schools that enables individuals to achieve emotional self-control. These results align with many other recent studies that report educational practices promoting emotional regulation $[1,11,12,27,28]$.

In view of this, the results here report significant changes regarding emotional regulation. In this sense, and following the theoretical approaches referred to, children first learn to identify their emotions by becoming aware of the present moment and, as a result, they gradually acquire the skills that enable them to have greater self-control $[26,29,31]$. The significant differences between the pre- and post-tests, as well as our observations of the approach, showed that the practice of mindfulness in educational practice helps students to identify and become aware of the emotions they feel, with this being the first crucial step towards being able to manage their emotional states. As a result, the implementation of introjective practices in physical education in schools can be used as a tool to develop emotional education with the appropriate guidance of the teacher.

Along these lines, the results obtained in this study through the three dimensions of emotional attention, clarity of feelings, and emotional repair provide interesting and relevant data, as discussed above. Likewise, the changes produced at the end of the intervention and recorded in the instrument used are a direct consequence of the educational intervention or, in other words, of what has occurred between the pre- and post-test; i.e., the introjective practices carried out. Moreover, the findings of this study are similar to those found in other studies insofar as they show that the practice of paying full attention reduces levels of nervousness and stress [16] and, at the same time, produces positive post emotions $[1,12,19,26]$. The internal logic of this activity helped to reduce negative emotional states and, by contrast, to bring out enthusiasm or positive states of mind, as revealed by other studies $[1,12,16,26]$.

Our investigation showed differences between the pre- and post-intervention by showing improvements in the attention dimension, with appropriate levels reached on completion of the project, as students were able to feel and express these feelings adequately. We also observed a significant result in the overall sample of girls after implementing the approach based on introjective PE practices, which means that girl students were highly aware of their emotional states, and these improved following the approach. The results obtained are in line with those of Extremera and Fernández-Berrocal [15], showing that with the practice of mindfulness, paying full attention provides 
an opportunity to become aware of one's emotions and therefore provides the tools needed by children to be able to control them, thus developing their personal well-being [1,26,27].

Nonetheless, this kind of introjective educational practice must be carried out over time and in a systematized way in order to produce changes in young people's attitudes $[1,28]$, such as establishing a systematized practice at school to address emotions, with more systematic work and a specific time and space throughout the whole school year to be able to help students self-regulate their emotions. In view of this, and according to Flook et al. [28], undertaking a task such as mindfulness is like learning to play an instrument or a sport; it requires both time and dedication.

The conclusion of this study shows how introjective practices provide primary school students with the tools with which to face the different problems they encounter in their daily lives, whether these are of a motor-based or emotional nature. The practices thus help to better understand their body and to control it without it controlling them, on the basis of the emotions they feel. In this sense, the practice of mindfulness can help achieve this goal, and as PE is conceived as a cross-disciplinary subject it provides an ideal space in which to achieve this.

\section{Prospects and Limitations}

We believe this article may be of interest to primary school teachers, since it helps reflect on the effect of introjective practices in the development of emotional self-regulation, verifying the existence of improvements between the before and after stages of educational intervention. This study therefore provides useful information for teachers, and specifically PE teachers, effectively promoting their motivational strategies towards a practice focused on the self-regulation of the emotions.

It is important to point out that this study has some limitations, such as the use of one single instrument in the form of the TMMS questionnaire. As such, future studies could consider widening the sample size and using other emotional competence scales to compare the results. The use of an instrument that only collects quantitative data also presents a clear limitation and future studies could use mixed methods, employing other instruments such as reflective diaries, to obtain qualitative data that would enrich the interpretation of the results. These kinds of studies should help to establish practices promoting full attention in a systematized way in schools throughout the entire school year, to help students become more aware of their emotions, using different resources to help students control them, and develop forms of emotional self-regulation that contribute towards their personal well-being.

Taking into account the results obtained and the objective established at the outset, we can state that significant improvements can be observed in students' levels of emotional regulation. Although this study has provided students with a significant step towards self-regulation, the limitations of the study mean that these results and conclusions have to be linked to any approach to physical education that fosters cognitive, motor, and emotional competences. That is, although this study presents the link between introjective practices and the emotional self-regulation they provide, no information was planned for or tested in terms of knowledge acquisition or promotion of motor competences. A key area would be to determine which introjective practice produces either cognitive, motor, or emotional competences. This could be attained by reformulating the whole approach with an entirely different process of assessment and evaluation.

Author Contributions: Conceptualization, D.C.; data curation, M.S.; formal analysis, M.S., D.R., and T.S.; investigation, D.C. and J.C.; methodology, M.S. and D.R.; software, M.S. and T.S.; supervision, D.C. and J.C.; validation, D.R.; writing—original draft, D.C., T.S., and J.C.; writing-review and editing, J.C. All authors have read and agreed to the published version of the manuscript.

Funding: This research was funded by the Institute of Sciences Education Josep Pallach of the University of Girona, grant number XIDAC20/1.

Conflicts of Interest: The authors declare no conflict of interest. 


\section{References}

1. Greenberg, M.T.; Harris, A.R. Nurturing mindfulness in children and youth: Current state of research. Child Dev. Perspect. 2011, 6, 1-6. [CrossRef]

2. Ato, E.; González, C.; Carranza, J.A. Aspectos evolutivos de la autorregulación emocional en la infancia. Ann. Psicol. 2004, 20, 69-79.

3. Cañabate, D.; Martínez, G.; Rodríguez, D.; Colomer, J. Analysing emotions and social skills in physical education. Sustainability 2018, 10, 1585. [CrossRef]

4. Cañabate, D.; Colomer, J.; Olivera, J. Movement: A language for growing. Apunts. Educación Física y Deportes 2018, 134, 146-155. [CrossRef]

5. Ayllón, S.; Alsina, Á.; Colomer, J. Teachers 'involvement and students' self-efficacy: Keys to achievement in higher education. PLOS ONE 2019, 14, e0216865. [CrossRef]

6. Cañabate, D.; Serra, T.; Bubnys, R.; Colomer, J. Pre-service teachers' reflections on cooperative learning: Instructional approaches and identity construction. Sustainability 2019, 21, 5970. [CrossRef]

7. Bisquerra, R. Educación emocional y competencias básicas para la vida. Rev. Inves. Educ. 2003, 21, 7-43. [CrossRef]

8. Colomer, J.; Serra, L.; Cañabate, D.; Serra, T. Evaluating knowledge and assessment-centered reflective-based learning approaches. Sustainability 2018, 10, 3122. [CrossRef]

9. Colomer, J.; Serra, T.; Cañabate, D.; Bubnys, R. Reflective learning in higher education: Active methodologies for transformative practices. Sustainability 2020, 12, 3827. [CrossRef]

10. Cañabate, D.; Nogué, L.; Serra, T.; Colomer, J. Supportive peer feedback in tertiary education: Analysis of pre-service teachers' perceptions. Educ. Sci. 2019, 9, 280. [CrossRef]

11. Alsina, A.; Ayllón, S.; Colomer, J. Validating the narrative reflection assessment rubric (NARRA) for reflective narratives in higher education. Assess. Eval. High. Educ. 2019, 44, 155-168. [CrossRef]

12. Rovira, G.; López-Ros, V.; Lavega, P.; Mateu, M. Las emociones en las prácticas motrices de atención plena. Rev. Esp. Orient. Psicol. 2014, 25, 111-126. [CrossRef]

13. Fernández-Berrocal, P.; Extremera, N.; Ramos, N. Validity and reliability of the Spanish modified version of the trait meta-mood scale. Psychol. Rep. 2004, 94, 751-755. [CrossRef]

14. Richman, L.S.; Kubzansky, L.; Maselko, J.; Kawachi, I.; Choo, P.; Bauer, M. Positive emotion and health: Going beyond the negative. Health Psychol. 2005, 24, 422-429. [CrossRef]

15. Extremera, N.; Fernández-Berrocal, P. La inteligencia emocional en el contexto educativo: Hallazgos científicos de sus efectos en el aula. Rev. Educ. 2003, 332, 97-116.

16. Lagardera, F. La lógica deportiva y las emociones. Implicaciones en la enseñanza del deporte. Apunts 1999, $56,99-106$.

17. Grewall, D.; Brackett, M.; Salovey, P. Emotional intelligence and the self-regulation of affect. In Emotion Regulation in Couples and Families: Pathways to Dysfunction and Health; Snyder, D.K., Simpson, A.J., Hughes, J.N., Eds.; American Psychological Association: Washington, DC, USA, 2006; pp. 37-55. [CrossRef]

18. Lavega, P.; Filella, G.; Agulló, M.J.; Soldevila, A.; March, J. Conocer las emociones al través del juego: Ayuda para los futuros docentes en la toma de decisiones. Electron. J. Res. Educ. Psychol. 2011, 24, 617-640.

19. Lavega, P.; March, J.; Filella, G. Juegos deportivos y emociones. Propiedades psicométricas de la escala GES para ser aplicada en la EF y el Deporte. Rev. Inv. Educ. 2012, 31, 151-165. [CrossRef]

20. Chacón, R.; Chacón, F.; Zurita, F.; Cachón, J.; Zagalaz, M.L.; Chinchilla, J.J. Characterization of motivation and type of physical-sport practice in adults through compass profiles. J. Hum. Sport Exercise 2018, 13, 161-173. [CrossRef]

21. Chacón, R.; Zurita, F.; Castro, M.; Espejo, T.; Martínez, A.; Pérez, A.J. Motivational climate in sport and its relationship with digital sedentary leisure habits in university students. Saúde e Sociedade 2017, 26, 29-39. [CrossRef]

22. Amutio-Kareaga, A.; Franco, C.; Gázquez, J.J.; Mañas, I. Aprendizaje y práctica de la conciencia plena en estudiantes de bachillerato para potenciar la relajación y la autoeficacia en el rendimiento escolar. Univ. Psychol. 2015, 14, 433-443. [CrossRef]

23. Weare, K. Developing mindfulness with children and young people: A review of the evidence and policy context. J. Child. Serv. 2013, 8, 141-153. [CrossRef] 
24. Black, D.S.; Milam, J.; Sussman, S. Sitting-meditation interventions among youth: A review of treatment efficacy. Rev. Treat. Effic. Pediatr. 2009, 124, 532-541. [CrossRef]

25. Eastman-Mueller, H.; Wilson, T.; Jung, A.K.; Kimura, A.; Tarrant, J. Irest yoga-nidra on the college campus: Changes in stress, depression, worry, and mindfulness. Int. J. Yoga Therapy 2013, 23, 15-24. [CrossRef]

26. Kuyken, W.; Weare, K.; Ukoumunne, O.C.; Vicary, R.; Motton, N.; Burnett, R.; Cullen, C.; Hennelly, S.; Huppert, F. Effectiveness of the Mindfulness in Schools Programme: Non-randomised controlled feasibility study. Br. J. Psychiatry 2013, 203, 126-131. [CrossRef]

27. Broderick, P.C.; Metz, S. Learning to BREATHE: A Pilot Trial of a Mindfulness Curriculum for Adolescents. Adv. Sch. Ment. Heal. Promot. 2009, 2, 35-46. [CrossRef]

28. Flook, L.; Smalley, S.L.; Kitil, M.J.; Galla, B.M.; Kaiser-Greenland, S.; Locke, J.; Ishijima, E.; Kasari, C. Effects of Mindful Awareness Practices on Executive Functions in Elementary School Children. J. Appl. Sch. Psychol. 2010, 26, 70-95. [CrossRef]

29. Sampedro, S.S.; Flores, A.A.; Tejero, J.P. Evolució del rendiment en nedadors paralímpics amb discapacitat física: De Pequín 2008 a Londres 2012. Apunts. Educación Física y Deportes 2016, 124, 41-48. [CrossRef]

30. Schonert-Reichl, K.A.; Lawlor, M.S. The Effects of a Mindfulness-Based Education Program on Pre- and Early Adolescents' Well-Being and Social and Emotional Competence. Mindfulness 2010, 1, 137-151. [CrossRef]

31. Rodríguez-Carvajal, R.; García-Rubio, C.; Paniagua, D.; García-Diex, G.; De Rivas, S. Modelo Integrador de Mindfulness (MIM): El cultivo de los estados mentales positivos hacia uno mismo y los demás a través del Mindfulness y la autocompasión. Anales de Psicología 2016, 32, 749. [CrossRef]

32. Ruiz, F.J. The relationship between low levels of mindfulness skills and pathological worry: The mediating role of psychological inflexibility. [La relación entre habilidades de mindfulness y preocupación patológica: El rol mediador de la inflexibilidad psicológica]. Anales de Psicología 2014, 30, 887-897. [CrossRef]

33. Canales, I.; Rovira, G. La importancia de la autorregulación y la empatía en la formación docente. Movimento 2016, 22, 157-172.

34. Cañabate, D.; Rodríguez, D.; Sánchez, M.L.Z. Physical education and dance: Assessment of inclusion and development in primary schools in Girona province. Apunts. Educación Física y Deportes 2016, 125, 53-62. [CrossRef]

35. Salovey, P.; Mayer, J.D.; Goldman, S.L.; Turvey, C.; Palfai, T.P. Emotional attention, clarity, and repair: Exploring emotional intelligence using the Trait Meta-Mood Scale. In Emotion, Disclosure, E Health; American Psychological Association (APA): Washington DC, USA, 2004; pp. 125-154. pp. 125-154.

36. Meiklejohn, J.; Phillips, C.L.; Freedman, M.L.; Griffin, M.L.; Biegel, G.; Roach, A.; Frank, J.L.; Burke, C.; Pinger, L.; Soloway, G.; et al. Integrating Mindfulness Training into K-12 Education: Fostering the Resilience of Teachers and Students. Mindfulness 2012, 3, 291-307. [CrossRef]

37. Zurita-Ortega, F.; Sanchez, M.C.; Manrique, M.L.; Cuberos, R.C. Resiliencia, un elemento de prevención en actividad física. Sport. Sci. J. Sch. Sport Phys. Educ. Psychomot. 2016, 3, 564. [CrossRef] 